\title{
NGUỒN NƯỚC NGỌT VÀ HỆ THỐNG THỦY ĐIỆN TRÊN SÔNG LAN THƯƠNG-MÊ CÔNG ĐANG TRỞ THÀNH "VŨ KHÍ CHIẾN LƯợC"
}

\author{
Cấn Thu Văn ${ }^{1}$ Đặng Trung Thuận ${ }^{2}$
}

Tóm tắt: Đồng bằng sông Cưu Long (ĐBSCL) là vùng Châu thổ sông Mê Công, ở phía nam Việt Nam có diện tích trên $40.000 \mathrm{~km}^{2}$, chiếm $12 \%$ tổng diện tích tư nhiên và gần $20 \%$ dân số cả nước. ĐBSCL là vùng trọng điểm về sản xuất nông nghiệp và đánh bắt, nuôi trồng thủy sản; phát triển mạnh kinh tế biển, du lịch sinh thái cảnh quan sông nước và có vai trò đặc biệt quan trọng về an ninh quốc phòng. Tuy nhiên trong bối cảnh hiện nay, cả nước nói chung và ĐBSCL nói riêng đang đứng trước nhũng nguy co khô cạn về mùa kiệt, ngập sâu về mùa lũ dưới tác động tù phía thuợng lưu dòng Lan Thuơng-Mê Công. Nghiên cứu bước đầu nhận định và phân tích nhũng nguy co truớc mắt và tiềm ẩn trên khía cạnh khoa học nước.

Từ khóa: Đồng bằng sông Cưu Long, sông Mê Công, Quản lý nguồn nước.

Ban Biên tập nhận bài: 20/12/2018 Ngày phản biện xong: 15/02/2019 Ngày đăng bài: 25/02/2019

\section{Tổng quan hệ thống sông Lan Thương- Mê Công}

Mê Công là một trong những sông lớn trên thế giới, bắt nguồn từ vùng núi cao tỉnh Thanh Hải, băng qua Tây Tạng, đi suốt chiều dài tỉnh Vân Nam Trung Quốc, chảy qua Lào, Myanma, Thái Lan, Campuchia và đổ ra Biển Đông ở Việt Nam. Mê Công dài $4.909 \mathrm{~km}$ đứng thứ 12 thế giới, thứ 7 tại châu Á với diện tích lưu vực khoảng $795.000 \mathrm{~km}^{2}$. Lượng nước đứng thứ 10 trên thế giới, hàng năm đạt khoảng 475 triệu $\mathrm{m}^{3}$. Lưu lượng trung bình $13.200 \mathrm{~m}^{3} / \mathrm{s}$, vào mùa nước lũ có thể lên tới $30.000 \mathrm{~m}^{3} / \mathrm{s}$. Tại Kratie Campuchia, trạm thủy văn trước đồng bằng có lưu lượng trung bình $12.869 \mathrm{~m}^{3} / \mathrm{s}$, lưu lượng lớn nhất đạt $36.297 \mathrm{~m}^{3} / \mathrm{s}$, nhỏ nhất đạt $2.000 \mathrm{~m}^{3} / \mathrm{s}$. Sông Mê Công gồm 3 đoạn: Đoạn sông Lan Thương, đoạn sông Mê Công và đoạn sông Cửu Long. Lan Thương là đoạn sông Mê Công trên

${ }^{1}$ Trưòng Đại học Tài nguyên và Môi trường TP.HCM

${ }^{2}$ Truoòng Đại hoc Khoa hoc tụ nhiên - Đại hoc Quốc Gia Hà Nội

Email:ctvan@hcmunre.edu.vn đất Trung Quốc với nhánh đầu nguồn bên tả ngạn từ vùng núi Tây Tạng ở độ cao hơn 5.000 $\mathrm{m}$. Nhánh đầu nguồn bên hữu ngạn từ vùng núi Thanh Hải ở độ cao hơn $6.000 \mathrm{~m}$.

Lưu vực sông Mê Công ở Việt Nam có diện tích khoảng $71.000 \mathrm{~km}^{2}$, chiếm hơn $8 \%$ diện tích toàn lưu vực và $20 \%$ diện tích Việt Nam. Lưu vực sông Mê Công ở Việt Nam có các sông như sau:Sông Nậm Rốm và Nậm Núa có diện tích lưu vực 1.650 km². Nậm Rốm bắt nguồn từ Bắc huyện Điện Biên qua thành phố Điện Biên Phủ - Pa Thơm (huyện Điện Biên) rồi chảy sang Lào; Các sông ở Tây Nguyên có diện tích lưu vực khoảng $29.700 \mathrm{~km}^{2}$. Tây Nguyên là thượng nguồn đối với Campuchia trong khi Đồng bằng sông Cửu Long là hạ nguồn cuối cùng của lưu vực sông Mê Công (Hình 1) [1, 2].

Sông Sê San, Srêpôk và Sê Konglà 3 sông nhánh chính phía bờ trái của sông Mê Công. Lưu vực của 3 sông này trên lãnh thổ Việt Nam nằm trên địa phận của 6 tỉnh: Kon Tum, Gia Lai, Đắk Lắk, Đắk Nông, Lâm Đồngvà Thừa Thiên Huế (Hình 2) [1]. 


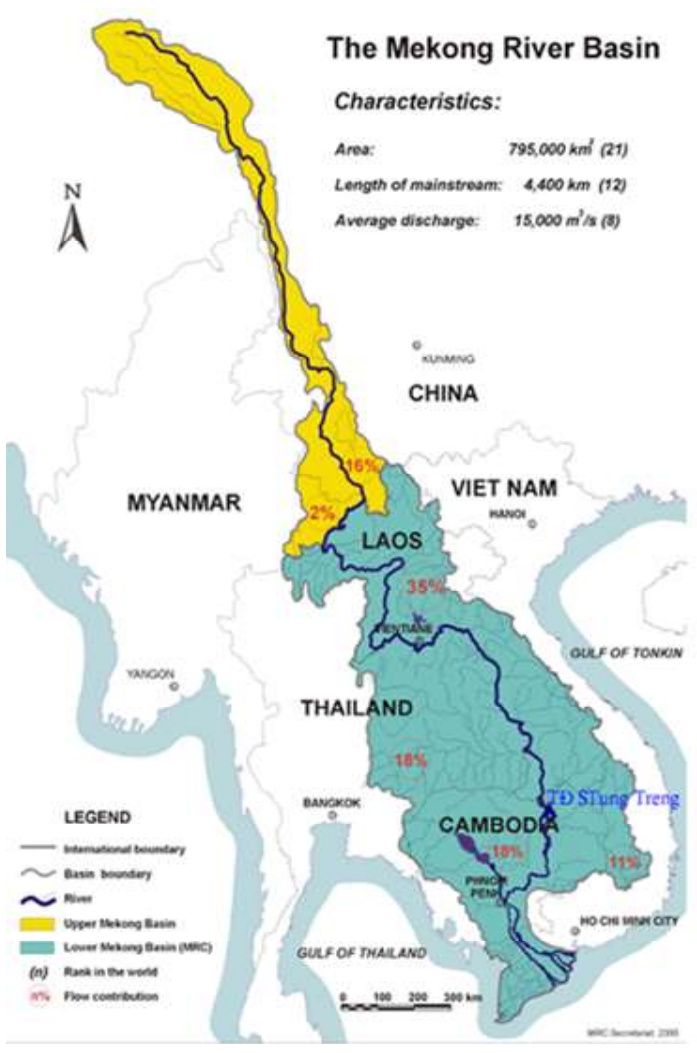

Hình 1. Hệ thống sông Lan Thưong-Mekong (Ủy hội sông Mekong)

Sông Sê San bắt nguồn từ vùng núi phía bắc và đông hai tỉnh Gia Lai và Kon Tum. Diện tích lưu vực sông Sê San thuộc lãnh thổ Việt Nam là $11.450 \mathrm{~km}^{2}$ với chiều dài dòng chính $252 \mathrm{~km}$ và mật độ lưới sông $0,38 \mathrm{~km} / \mathrm{km}^{2}$. Từ phía bắc tỉnh Kon Tum, sông Sê San chảy theo hướng gần bắc nam đến tuyến công trình thủy điện Ialy rồi rẽ sang hướng gần tây nam chảy ra biên giới Việt Nam - Campuchia. Cao độ bình quân lưu vực Sê San là $737 \mathrm{~m}$ trên mực nước biển, độ dốc bình quân khoảng 14,4\%.

Sông Srêpôk bắt nguồn từ các tỉnh Đắk Lắk và Lâm Đồng với diện tích lưu vực trong lãnh thổ Việt Nam khoảng $12.030 \mathrm{~km}^{2}$, chiều dài dòng chính $291 \mathrm{~km}$ và mật độ lưới sông $0.55 \mathrm{~km} / \mathrm{km}^{2}$. Hai nhánh chính của sông Srêpôk làKrông Knô và Krông Ana.

Sông Sêkong bắt nguồn từ dãy núi Trường Sơn (vùng Aso), huyện A Lưới, tỉnh Thừa Thiên Huế. Toàn bộ lưu vực Sêkong rộng 29.750 km²

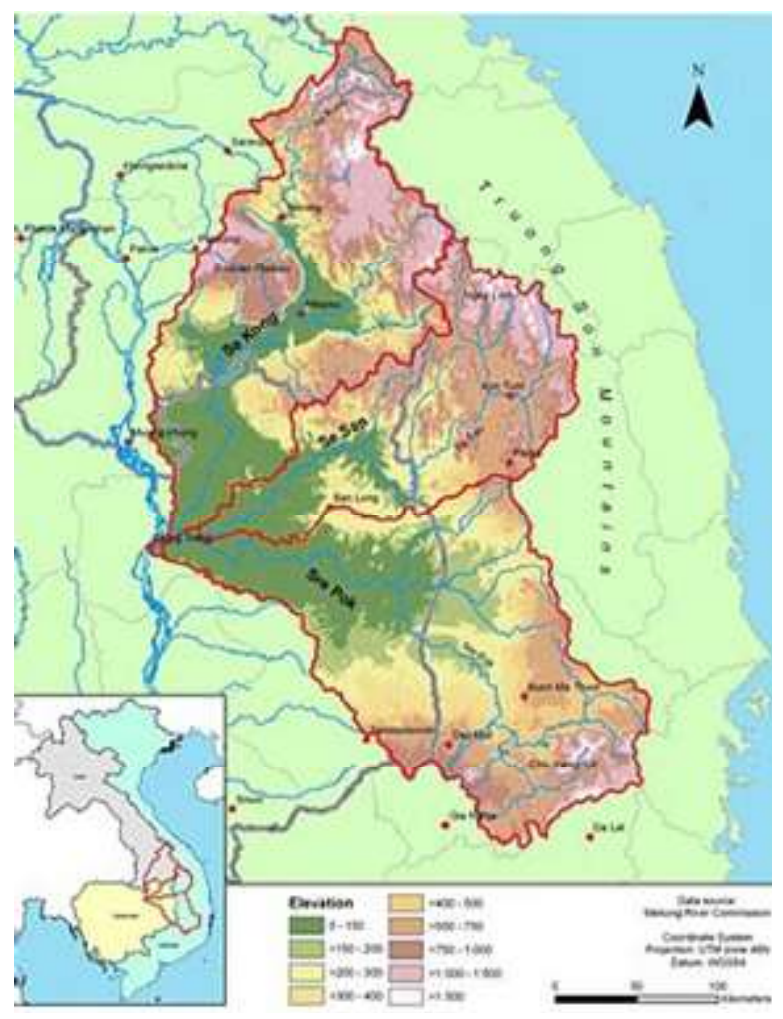

Hình 2. Hệ thống sông Sê San, Srêpôk

trong đó phần trên lãnh thổ Việt Nam là 750 km².

Đồng bằng sông Cửu Long: Sông Mê Công khi chảy xuống hạ lưu Phnôm Pênh vào Việt Nam được chia thành 2 nhánh chính là sông Tiền và sông Hậu từ đó chia ra nhiều nhánh nhỏ đổ ra biển Đông, tạo nên Đồng bằng sông Cửu Long (ĐBSCL).

ĐBSCL ở phía nam Việt Nam có diện tích trên $40.000 \mathrm{~km}^{2}$, chiếm $12 \%$ tổng diện tích tự nhiên cả nước, có ranh giới tây bắc là biên giới Việt Nam - Campuchia, phía đông bắc là sông Vàm Cỏ Đông, phía đông nam là Biển Đông và tây nam là Vịnh Thái Lan. ĐBSCL bao gồm 13 tỉnh, thành: Long An, Tiền Giang, Đồng Tháp, Vĩnh Long, Trà Vinh, Hậu Giang, Sóc Trăng, Bến Tre, An Giang, Kiên Giang, Bạc Liêu, Cà Mau và thành phố Cần Thơ trực thuộc trung ương $[3,4]$. 


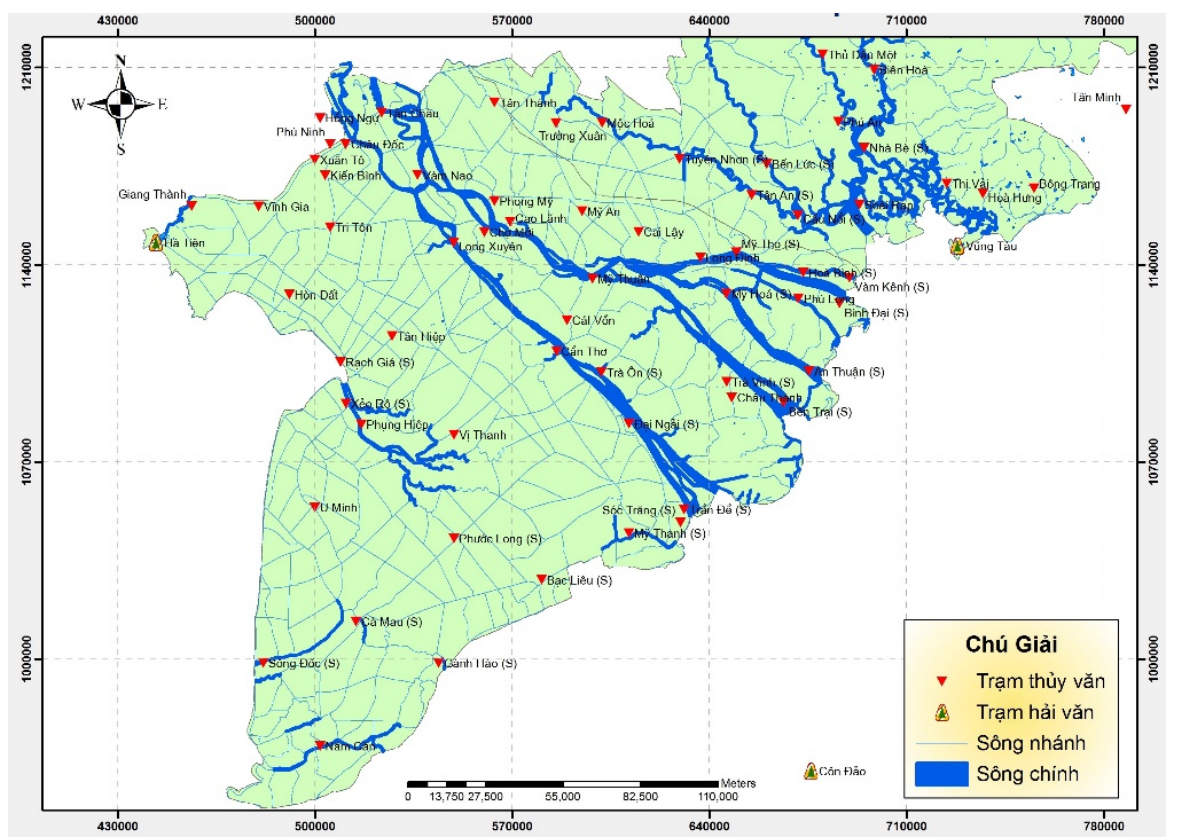

Hình 3. Vùng đồng bằng sông Cưu Long

2. Nước và hệ thống thủy điện trên sông Lan Thương-Mê Công là "vũ khí chiến lược"

2.1. Hệ thống thủy điện trên sông Lan Thương-Mê Công

Trên dòng chính sông Mê Công đã quy hoạch hơn 19 công trình sử dụng nước, xây dựng đập thủy điện lớn, trong đó Trung Quốc: 6 đập đã hoàn thành đi vào vận hành, 1 đập đang xây, 2 trong quy hoạch; Lào: 2 đập sắp hoàn thành, 1 đập đang xây dựng, 2 đập đã nghiên cứu tiền khả thi, 4 đập trong quy hoạch; Campuchia có 2 thủy điện lớn trong quy hoạch: Stung Chen và Sambor. Ngoài ra còn có hàng chục hồ đập thủy điện trên các phụ lưu của Mê Công trên đất Thái Lan, Lào, Campuchia và Việt Nam $[5,6]$.

Bảng 1. Hệ thống thủy điện bậc thang trên dòng Lan Thuoong - Trung Quốc

\begin{tabular}{|c|c|c|c|c|}
\hline STT & Tên đập & Công suất & Cao độ & Hiện trạng \\
\hline 1 & Miaowei - Miêu Vĩ & $\begin{array}{l}\text { Cao } 140 \mathrm{~m}, 1.400 \mathrm{MW} \text { Dung } \\
\text { tich } 660 \text { tr. } \mathrm{m}^{3}\end{array}$ & $1300 \mathrm{~m}$ & Đã vận hành \\
\hline 2 & $\begin{array}{l}\text { Gongguoqiao } \\
\text { Công Quả Kiều }\end{array}$ & Cao $105 \mathrm{~m}$, hồ chứa nước & - & Vận hành từ 2016 \\
\hline 3 & Xiaowan - Tiểu Loan & $\begin{array}{l}\text { Cao } 292 \mathrm{~m}, 4.200 \text { MW Dung } \\
\text { tích } 15 \text { tỷ } \mathrm{m}^{3}\end{array}$ & - & Vận hành từ 2009 \\
\hline 4 & Manwan - Mạn Loan & $\begin{array}{l}\text { Cao } 132 \mathrm{~m}, 1.500 \mathrm{MW} \text { Dung } \\
\text { tích } 920 \text { tr.m }\end{array}$ & $1000 \mathrm{~m}$ & Vận hành từ 1993 \\
\hline 5 & $\begin{array}{l}\text { Dachaoshan } \\
\text { Đại Triều Sơn }\end{array}$ & $\begin{array}{l}118 \mathrm{~m}, 1.350 \mathrm{MW} \\
\text { Dung tích } 940 \text { tr.m }\end{array}$ & - & Vận hành từ 2003 \\
\hline 6 & $\begin{array}{l}\text { Nuozhadu } \\
\text { Nọa Trát Độ }\end{array}$ & $\begin{array}{l}\text { Cao } 262 \mathrm{~m}, 5.850 \mathrm{MW} \text { Dung } \\
\text { tích } 21,749 \text { tỷ } \mathrm{m}^{3}\end{array}$ & $812 \mathrm{~m}$ & Vận hành từ 2014 \\
\hline 7 & $\begin{array}{l}\text { Jinghong - Cánh } \\
\text { Hồng }\end{array}$ & $\begin{array}{l}\text { Cao } 107 \mathrm{~m} ; 1.500 \mathrm{MW} \text { Dung } \\
\text { tích } 249 \text { tr. } \mathrm{m}^{3}\end{array}$ & - & Vận hành từ 2003 \\
\hline 8 & Ganlanba - Cam Lâm & & - & Quy hoạch \\
\hline
\end{tabular}


Bảng 2. Hệ thống thủy điện bậc thang trên dòng Mê Công

\begin{tabular}{cllcc}
\hline STT & \multicolumn{1}{c}{ Tên đập } & \multicolumn{1}{c}{ Công suất } & Quốc gia & Hiện trạng \\
\hline 1 & Pak Beng & $1.320 \mathrm{MW}$ & Lào & Khởi động XD \\
2 & Luang Prabang & $1.410 \mathrm{MW}$ & Lào & VNNC Tiền khả thi \\
3 & Xayabouri & $1,260 \mathrm{MW}$ & Lào & Hoàn thành2019 \\
4 & Pak Lay & $1.320 \mathrm{MW}$ & Lào & Quy hoạch \\
5 & Sanakham & $1.000 \mathrm{MW}$ & Lào & Quy hoạch \\
6 & Pak Chom & $1.079 \mathrm{MW}$ & Lào - Thái Lan & Quy hoạch \\
7 & Ban Koum & $2.330 \mathrm{MW}$ & Lào - Thái Lan & Quy hoạch \\
8 & Lat Sua & $800 \mathrm{MW}$ & Lào & Quy hoạch \\
9 & Don Sahong & $260 \mathrm{MW}$ & Lào & Sắp hoàn thành \\
10 & Stung Treng & $980 \mathrm{MW}$ & Campuchia & VNNC Tiền $k h a ̉$ thi \\
11 & Sambor & $2.600 \mathrm{MW}$ & Campuchia & Quy hoạch \\
\hline
\end{tabular}

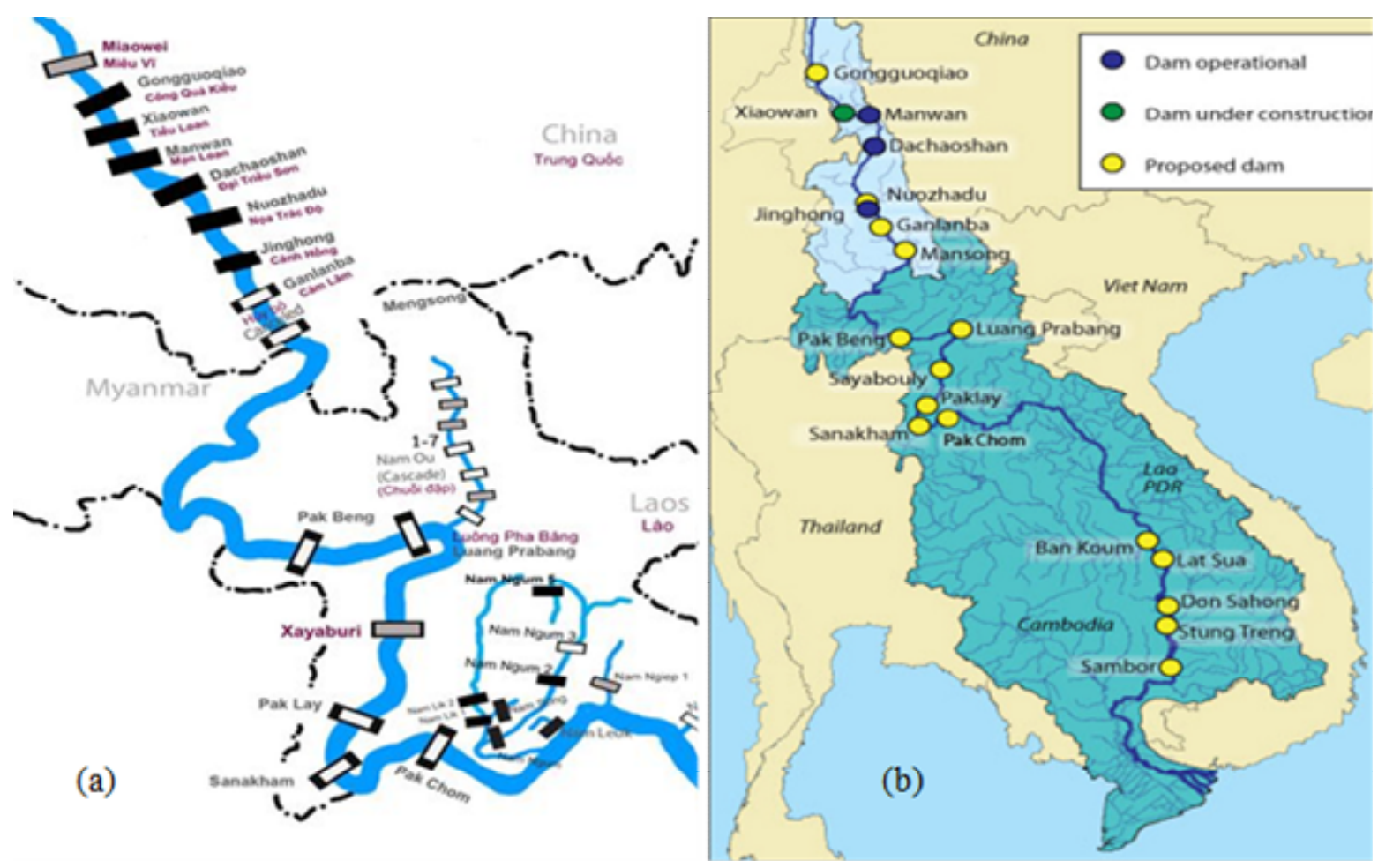

Hình 4. (a) Hệ thống thủy điện 2016; (b) Hệ thống thủy điện trước 2009 (Ủy hội sông Mê Công)

2.2. Tác động tự nhiên do hệ thống thủy điện đến ĐBSCL

\subsubsection{Tác động trước mắt}

Sông Mê Công đổ vào ĐBSCL lượng nước rất lớn, trung bình 475 tỉ m³/năm, chiếm 53-57\% tổng lượng dòng chảy toàn lãnh thổ Việt Nam.
Lượng mưa tại chỗ ở ĐBSCL 1.400- 2.200 $\mathrm{mm} /$ năm (khoảng 56-88 tỷ $\mathrm{m}^{3}$ ), chỉ bằng $1 / 7$ lượng nước từ Mê Công. Nước ngọt ở ĐBSCL trước đây rất đồi dào. Là nguồn cung cấp nước cho các đô thị và nông thôn rộng lớn; nuôi sống hệ thống kênh rạch và các dòng sông đổ ra biển 
qua 9 của rồng; cấp nước cho các ngành kinh tế nhất là nông nghiệp với hàng triệu ha gieo trồng; là môi trường di cư của các loài cá kinh tế và cả quý hiếm; đẩy lùi xâm nhập mặn trên diện rộng; tạo ra đời sống no đủ cho hàng chục triệu người Việt Nam.

Theo Ủy hội sông Mê Công (MRC) khi cả chuỗi thủy điện trên dòng chính sông Mê Công gồm 8 của Trung Quốc và 3 của Lào cùng đi vào vận hành thì tổng lượng nước Mê Công sẽ giảm $27 \%$ / tháng và xâm nhập mặn trên sông Tiền và sông Hậu vào sâu thêm 10-18km (vượt quá Mỹ Tho và Cần Thơ) so với hiện nay. ĐBSCL hình thành cách đây 6.000 năm, từ đó phù sa Mê Công bồi đắp, mở rộng ĐBSCL về phía Đông khoảng 26m/năm; về phía mũi Cà Mau $16 \mathrm{~m} /$ năm. Nhưng trong thời gian 20 năm gần đây sạt lở bờ biển gia tăng, có nơi bờ lùi, biển tiến vào nội đồng hơn $50 \mathrm{~m}$.

Số liệu từ MRC: Vào năm 1994 sông Mê Công cung cấp lượng phù sa lên đến 160 triệu tấn/năm ra khu vực cửa biển, nhưng đến năm 2014 chỉ còn lại 75 triệu tấn/năm. Thời kỳ 19791982, vào mùa lũ, hàm lượng phù sa lơ lửng của Mê Công vào sông Hậu tại Châu Đốc bình quân $250 \mathrm{~g} / \mathrm{m}^{3}$ và sông Tiền tại Tân Châu là $550 \mathrm{~g} / \mathrm{m}^{3}$. Trong mùa khô, hàm lượng phù sa lơ lững sông Tiền và sông Hậu dao động $30-80 \mathrm{~g} / \mathrm{m}^{3}$. Trong thời kỳ 2009-2015, vào mùa, lũ hàm lượng phù sa lơ lửng tại Châu Đốc gần $200 \mathrm{~g} / \mathrm{m}^{3}$; tại Tân Châu xấp xỉ $300 \mathrm{~g} / \mathrm{m}^{3}$. Vào mùa khô hàm lượng phù sa lơ lửng tại Châu Đốc và tại Tân Châu khoảng $30-80 \mathrm{~g} / \mathrm{m}^{3}$.

Thủy điện làm giảm lượng phù sa: về mùa khô phù sa lơ lửng và bùn cát di đáy lắng đọng lại trong dung tích chết trước đập, hệ quả phù sa không thể về xuôi, trừ khi có lũ. Thiếu hụt phù sa dẫn đến hệ lụy là ĐBSCL bị suy thoái, cao trình đồng bằng hạ thấp, xâm nhập mặn vào nội đồng trên diện rộng.Ngoài ra những tác động của hệ thống thủy điện ở đây còn: - Các tác động tới dòng chảy, nhịp lũ, hệ sinh thái, phù sa, thủy sản; - Các tác động đến sinh kế người dân, quy hoạch thủy lợi, phát triển nông nghiệp vùng ĐBSCL... Năm 2010 Các ngân hàng Mỹ, châu Âu ước tính sản lượng đánh bắt cá hằng năm tại lưu vực sông Mê Công - giá trị tương đương 7 tỉ USD - sẽ bị giảm xuống còn $70 \%$ do các đập xây dựng trên dòng chính của sông. Các đập thủy điện của Trung Quốc phía thượng nguồn sẽ giữ lại khoảng 50\% lượng phù sa, và nếu các con đập phía hạ lưu sông Mê Công được xây dựng thì có thêm khoảng 25\% lượng phù sa nữa bị ngăn lại. Như vậy, lượng phù sa vào vùng ĐBSCL của Việt Nam sẽ giảm đáng kể, từ 26 triệu tấn/năm chỉ còn khoảng 7 triệu tấn/năm.Như vậy, sự tồn vong của ĐBSCL và con người nơi đây gắn chặt với lượng nước và lượng phù sa của Mê Công. Vấn đề này cần được giải quyết thế nào?

\subsubsection{Rủi ro môi trường}

Rủi ro vỡ đập do lũ đột biến trong mối liên quan với biến đổi khí hậu, có thể giảm thiểu khi thiết kế công trình. Rủi ro do chất lượng xây dựng kém của thủy điện.Ví dụ, Đập thủy điện XePian-Xe Namnoy ở tỉnh Attapeu, Lào bị vơ vào đêm 23/7/2018 làm cho hàng trăm người mất tích và thiệt mạng, nhiều bản, làng ngập trong nước bùn, nhà cửa đổ nát, có thể phòng tránh khi thi công xây dựng công trình. Rủi ro do động đất. Thượng nguồn Mê Công nằm trong vùng động đất. Từ 1970- 2010 có 5 trận động đất lớn 5,1-7,5 độ Richter làm chết và bị thương nhiều người, hư hại nhiều nhà cửa, làng mạc.

Các đập thủy điện và hồ chứa nước sông Lan Thương ở thượng lưu Mê Công đều lớn, cao, luôn tiềm ẩn nguy cơ đổ vỡ do động đất, có thể dẫn đến hiệu ứng dây chuyền đôminô vỡ đập đáng sợ.Vỡ đập thủy điện trên sông Lan Thương sẽ là thảm họa môi trường cho các địa phương ven sông ở trung và hạ du Mê Công và cả ĐBSCL.

\subsubsection{Tác động lâu dài}

Hệ thống thủy điện và hồ chứa nước trên dòng chính sông Mê Công có thể gây ra nhiều tác động lâu dài đến ĐBSCL, bao gồm: Thay đổi chế độ thủy văn sông Mê Công. Giảm lượng nước đổ về hạ du; Tương tác sông biển với ưu thế của biển và hệ lụy xâm nhập mặn. Nước mặn vào sâu trong song. Thiếu nước ngọt cho các ngành kinh tế; Thay đổi hệ sinh thái cửa sông 
ven biển. Hệ sinh thái nước ngọt dần bị thay thế bởi hệ sinh thái nước mặn lợ; Thiếu nước ngọt cho cây trồng, cho con người và vật nuôi. Sự sống ở ĐBSCL dần thay đổi.

\subsection{Vũ khí chiến lược}

2.3.1. Sự phu thuộc vào nước ngoài về nguồn ni̛ớc

Năm 1957 Ủy ban sông Mê Công được thành lập, gồm 4 nước: Thái Lan, Lào, Campuchia và Việt Nam. Myanma và Trung Quốc là 2 nước đối tác đối thoại. Ủy ban hoạt động trong giai đoạn 1957- 1976, có một điều ước cơ bản là “mỗi nước có quyền phủ quyết một dự án nào có hại đến dòng chính sông Mê Công”. Năm 1995 đổi tên thành Ủy hội sông Mê Công và thay đổi điều ước cơ bản thành "không một thành viên nào có quyền phủ quyết một dự án nào có hại đến dòng chính sông Mê Công”. Từ đó, Việt Nam ở cuối hạ lưu Mê Công là nước bị thiệt thòi nhất.

Năm 2011 Lào chuẩn bị khởi công xây dựng thủy điện Xayaburi, Việt Nam phản đối. Tại hội nghị ASEAN Thủ tướng Việt Nam đã gặp Thủ tướng Lào về vấn đề này. Sáu tháng sau Lào trả lời là: "Thủy điện Xayaburi không gây hại Việt Nam”, họ đã khởi công xây dựng và năm 2019 này sẽ hoàn thành.Giữa năm 2016 hạn hán lớn ở ĐBSCL, ruộng đồng khô nứt nẻ, Chính phủ Việt Nam đã đề nghi “cầu cứu” và Trung Quốc đã xả nước hồ đập thủy điện Cánh Hồng để chống hạn cứu lúa ở ĐBSCL. Điều này chứng tỏ là ĐBSCL rất phụ thuộc vào nguồn nước từ nước ngoài.

\subsubsection{Nước trở thành "vũ khi chiến lược"}

Như đã biết,nước là loại tài nguyên đặc biệt, nuôi sống hàng tỉ người trên hành tinh Trái đất, nhưng với những thế lực có mưu đồ xấu thì nước có thể trở thành vũ khí giết người hàng loạt hơn cả đao kiếm.Nước không phải là vũ khí nóng, mà là vũ khí nguội nhưng rất sắc bén. Một tia nước nhỏ, với tốc độ lớn, có động năng lớn, có thể chọc thủng tấm nhôm. Tổng khối lượng nước của hệ thống hồ chứa trên dòng Lan Thương chiếm 50\% lượng nước của Mê Công, khoảng 237,5 tỷ $\mathrm{m}^{3} / \mathrm{năm}$. Trên khoảng dài $600 \mathrm{~km}$ dọc sông Lan Thương đã hình thành hệ thống bậc thang thác nước từ Bắc xuống Nam cao lần lượt là: 140 - 105 - 292 - 132 - 118 - 262 - 107 m tại các vị trí có cao độ (m): 1.300 - 1.000 - 812 m. Tổng dung tích của 5 hồ Thủy điện lớn là 39,269 tỷ $\mathrm{m}^{3}$, do vậy cùng lúc có thể tạo ra một động năng lớn, với sức tàn phá kinh khủng. Sông Lan Thương có khối lượng nước lớn, trắc diện hinh chữ $\mathrm{V}$, lòng sông hẹp, độ dốc lớn sẽ sinh ra vận tốc dòng chảy lớn,theo đó động năng dòng nước sẽ lớn, có sức công phá mạnh những vật cản trên sông.

Vấn đề đặt ra là: trong một thời điểm nào đó, cần có một sự trao đổi hoặc ép buộc về mặt chính trị nào đó, liệu quốc gia phía thượng lưu có ý đồ xấu lợi dụng dòng nước Lan Thương để gây ngập lụt, hoặc tạo hạn hán ở vùng ĐBSCL hay không? Vì rằng: Khi hệ thống thủy điện xả nước khẩn cấp theo "mệnh lệnh của cấp có thẩm quyền",chắc chắn là ĐBSCL bị ngập lũ nặng: Nhà cửa đổ nát, ruộng vườn tan hoang, cây trồng vật nuôi chết trôi, chết chìm, đường sá hư hỏng. Số ít người dân có thể thoát chết bằng cách sống trên ghe thuyền với 2 bàn tay trắng. Tính chiến lược của vũ khí nước là đây! Thủy điện trên sông Lan Thương quyết định vận mệnh của ĐBSCL. Thủy điện thượng lưu có thể vận hành: (i) Xả nước để gây ngập lụt và làm“chết đuối” hiệu quả nhất vào mùa mưa; (ii) Tích nước để gây hạn hán và gây "chết khát", cuối cùng là "chết đói" ở ĐBSCL - hiệu quả nhất vào mùa khô. Tính chiến lược đa năng của vũ khí nước là đây!

Những năm nước lớn, lượng nước đổ về ĐBSCL: Mùa kiệt 92,8 tỷ $\mathrm{m}^{3}$, mùa lũ 388 tỷ $\mathrm{m}^{3}$; Những năm nước thấp, lượng nước đổ về ĐBSCL: Mùa kiệt 79,8 tỷ $\mathrm{m}^{3}$, mùa lũ 326 tỷ $\mathrm{m}^{3}$. Riêng dung tích của 2 Hồ chứa thủy điện ở cuối dòng Lan Thương (Cánh Hồng + Nọa Trát Độ) là: 22 tỷ $\mathrm{m}^{3}$ nước. Thừa nước để điều tiết lượng nước chiến lược về ĐBSCL với 2 kịch bản: (i) Vào mùa mưa, với chiêu thức "tát nước theo mưa”, thủy điện trên sông Lan Thương xả lũ, gây ngập lụt sâu, rộng, làm cho ĐBSCL chết trôi, chết chìm. (ii) Vào mùa kiệt, với chiêu bài "dừng phát điện để bảo trì nhà máy”, không cho nước về xuôi, gây ra hạn hán khốc liệt, làm cho 
ĐBSCL chết khô, chết khát và lâm vào cảnh bi đát.

\section{Kết luận}

Ngày càng rõ nét rằng Việt Nam đang trong tình cảnh bị sức ép rất to lớn từ 2 phía: Phía Đông là nguy cơ chiến tranh nóng với bàn đạp là Biển Đông cùng các loại vũ khí hiện đại, gây ra chết người hàng lọat trong khoảnh khắc; Phía Tây là chiến tranh nguội với bàn đạp là dòng Mê Công và vũ khí chiến lược là nước. Tuy nhiên, trong bối cảnh thế giới ngày nay, chiến tranh nóng rất ít khả năng xảy ra. Ngược lại, chiến tranh nguội từ dòng nước Lan Thương phía Tây có khả năng diễn ra với xác suất lớn, vì rằng đây là cuộc chiến âm thầm, lặng lẽ, gây ra cái chết dần dần, nhưng hệ lụy sẽ là thảm họa về xã hội và môi trường đối với đồng bằng sông Cửu Long. Trong bối cảnh đó, cần có những giải pháp và kế sách tổng thể mang tầm chiến lược để đối phó với chiến tranh nguội và ứng cứu cho đồng bằng sông Cửu Long, đảm bảo phát triển bền vững vùng đất rộng lớn, giàu tài nguyên này. Nội dung này sẽ được trình bày trong bài báo tiếp theo.

\title{
Tài liệu tham khảo
}

1. Tô Quang Toản (2015), Nghiên cưu các khả năng phát triển thượng lưu tác động đến chế độ dòng chảy và xâm nhập mặn mùa khô ở Đồng bằng sông Cửu Long. Luận án thuộc chuyên ngành Kỹ thuật tài nguyên nước, Viện Khoa học thủy lợi

2. Viện Khoa học Thủy lợi Miền Nam, (2005), Co sở khoa họ xây dụng đê bao bờ bao ĐBSCL, Báo cáo tổng kết Đề tài Nhà nước năm 2003-2005.

3. Viện Khoa học Thủy lợi Miền Nam (2006), Nghiên cứu xây dưng co sở dũ liệu đê bao bò̀ bao và đánh giá tác động của việc xây dựng đê bao bò̀ bao đến kinh tế, xã hội và môi trương ở châu thổ sông Mekong”, Báo cáo tổng kết Đề tài cấp Bộ Nông nghiệp và Phát triển nông thôn 2006;

4. Nguyễn Đinh Tuấn và cộng sự, (2015), Nghiên cưu xây dựng hệ hỗ trợ ra quyết định trong quản lý tài nguyên đất và nước vùng ĐBSCL trong bối cảnh biến đổi khi hậu, Đề tài cấp nhà nước thuộc chương trình mục tiêu quốc gia ứng phó biến đổi khí hậu, MS: BĐKH.20

5. Cấn Thu Văn, Nguyễn Thanh Sơn, (2016), Nghiên cưu thiết lập phioong pháp co bản đánh giá rủi ro lũ lut ở đồng bằng sông Cưu Long, Tạp chí Khoa học ĐHQGHN. Các Khoa học Trái đất và Môi trường, Tập 32, Số 3S, 2016264

6. Viện Khoa học Khí tượng Thủy văn và Biến đổi khí hậu (2015), Báo cáo đặc biệt của Việt Nam về quản lý rủi ro thiên tai và hiện tượng cực đoan nhằm thúc đẩy thích úng $B Đ K H$.

\section{THE IMPORTANCE OF WATER SOURCE AND HYDRAULIC SYS- TEMS ON RIVER LANCANG - MEKONG Can Thu Van ${ }^{1}$, Dang Trung Thuan ${ }^{2}$ \\ ${ }^{1}$ Ho Chi Minh city University of Natural Resources and Environment ${ }^{2}$ Hanoi University of Science- Vietnam Nation University Hanoi}

\begin{abstract}
The Mekong Delta in southern Vietnam covers an area of over 40,000 km², accounting for $12 \%$ of the total natural area and nearly $20 \%$ of the country's population. The Mekong Delta is a key area of agricultural production, fishing and aquaculture; marine economy, ecotourism and has a particularly important role in national security. However, at present, the Mekong Delta is facing the risk of drying up in dry season, deeply flooding in the flood season under the impact of upstream Lancang-Mekong River. This study initially identifies and analyzes the immediate and potential risks in the water science aspect.
\end{abstract}

Keywords: Mekong delta, Mekong river, water source. 